\title{
Protest and principle in state welfare
}

Jason Annetts

Alex Law

Wallace McNeish

Gerry Mooney

This is a post-peer-review, pre-copy edited version of a chapter published in Understanding social welfare movements.

Details of the definitive published version and how to purchase it are available online at:

https://policy.bristoluniversitypress.co.uk/ understanding-social-welfare-movements 


\section{Chapter 1}

\section{Protest and Principle in State Welfare}

\section{Introduction}

What part did social movements play in the formation of state welfare? Many accounts relegate social movements to a footnote in the development of state welfare while emphasising the role played by politicians, professional bodies and state administrators. Yet more was involved than the benevolent actions of a few elite individuals and groups. This chapter examines the prehistory of state welfare and explores the role attributed to social movements from competing social scientific perspectives. In order to do so, we compare perhaps the most influential account of the rise of the welfare state as expressing social rights, namely T.H. Marshall's (1950) lecture and essay 'Social Class and Citizenship', to 'one of the earliest and finest Marxist analyses of the welfare state' (Mishra, 1981: 75), that of John Saville's essay 'The Welfare State: An Historical Approach' (1957-8). Both accounts appeared at a precise historical moment, that of the post-war, high watermark for the egalitarian hopes that were placed in state welfare in Britain. Since this moment is often viewed in retrospect as a 'golden age' for state welfare, revisiting the analyses of leading British social scientists and historians of that age provides us with a measure of how they accounted for the role played by social movements from below.

Both Marshall and Saville locate state welfare within a wider socio-historical trajectory in the development of British social policy. The major faultline that this chapter focuses on is the debate between idealist and materialist approaches to the history of welfare. Marshall tends to picture this as a smooth line in the almost inevitable development of the ideal of social rights while Saville tends to emphasise the social conditions that lie behind the discontinuous and contingent nature of social rights. This allows us to 
compare their respective accounts according to the sociological precept that people make history in conditions that they do not choose. Social reform therefore occurs in a historical conjuncture which contains the following elements: constraints and possibilities imposed by objective institutional structures; some combination of historical continuities and discontinuities represented by a crisis like war or social upheaval; the role played by values, ideas and principles; and a willingness of broad masses of people to undertake popular mobilisation from below. In contrast to the hegemony of the top-down social administration school represented by Marshall and others we are at pains in this book to restore the bottom-up element in the contested and contentious politics of state welfare. More reflection of the role played by social movements and direct action provides a long overdue antidote to what EP Thompson called 'the condescension of posterity' in the erasure of struggles from below in many accounts of the establishment of social policy.

\section{Citizenship rights: A Whig history}

Perhaps the most famous sociological account of the rise of state welfare was penned some sixty years ago by T.H. Marshall (1950) in his celebrated essay 'Citizenship and Social Class'. Marshall was Professor of Sociology at the London School of Economics (LSE), which was founded in 1883 by the Fabian socialists Sidney and Beatrice Webb. A social reformist colouration was stamped on Sociology at the LSE with the overlap between Fabian socialism and the 'New Liberalism' of the late nineteenth and early twentieth centuries (Halsey, 2004). This social reformist confluence, known as 'LibLabism' after its peculiar mixture of Liberalism and Labourism, resulted in the dominance at the LSE of the tradition of social scientific investigation known as 'social administration'. Social administration emphasised empirical research as essential to underpin pragmatic, practical solutions to social problems from the top downwards, a tradition that is alive and well in the dominant approach of today's 'evidence-based social policy'. Social administration sat within a distinctively British intellectual approach to distinctively British social problems and the assumed civilising mission of Britain at home and abroad. Its intellectual underpinning, British Idealism, appealed to the rational mind, or social conscience, that the empirical 
evidence for reform was compelling and that the reforms themselves required careful management by qualified experts in social administration, objective bureaucracy and welfare professionalism.

New Liberalism advocated an interventionist role for the state to ensure that all citizens in the national community are able to exercise the positive freedom to participate fully in its political and cultural life. In 1907 a leading New Liberal, L.T. Hobhouse, was appointed by the LSE to the UK's first professorship in the relatively new discipline of sociology (Halsey, 2004). In his major work The Elements of Social Justice (1922) Hobhouse rooted the case for citizenship-based welfare reform within a tradition of Idealist social philosophy. Idealism in this context assumes that social reform can be achieved by appeals to rational dialogue and moral sentiment, leading to a change in the minds of doubters and sceptics. British Idealism influenced the development of sociology in Britain through Hobhouse's evolutionary approach to a 'social mentality' which holds communities together through shared social norms. Communities evolve most efficiently where individuals have the capacity and opportunity to develop as freely interacting, equal personalities, adapting social norms in the process. Therefore state intervention is permitted to create equal opportunities for personal growth and remove unnecessary constraints on inter-personal development like poverty, ignorance, sickness and destitution. As Marshall (1950: 16) expressed it:

The duty to improve and civilize oneself is therefore a social duty, and not merely a personal one, because the social health of a society depends upon the civilization of its members. And a community that enforces this duty has begun to realize that its culture is an organic unity and its civilization a national heritage.

Class antagonisms were to be mitigated by a nationalist pride in Imperial British values, a racially-based sense of superiority, and the subordination of women through an ideology of motherhood to the role of efficient procreation for the nation (Williams, 1989). This tradition culminated in the Beveridge Report of 1942, whose attack on the 'five evils' of Disease, Want, Squalor, 
Ignorance and Idleness aimed to raise the status of (male) British citizens through addressing material deficiencies in ways that were thought compatible with a market economy, the British empire and the patriarchal family structure.

Within this tradition Marshall set out his classical approach to citizenship in the immediate post-war period (1949) just when it appeared that the inequalities of social class might be ameliorated - though certainly not abolished - by the equal rights conferred by full citizenship of a national community. Indeed Marshall (1950: 7) argued that equal rights helped to legitimate class inequalities, 'so much so that citizenship has itself become, in certain respects, the architect of legitimate social inequality'. Overall, however, market-based inequalities were thought by Marshall to be lessening under the impact of state-led equalities of citizenship. 'The urge forward along the path thus plotted is an urge towards a fuller measure of equality, an enrichment of the stuff of which status is made and an increase in the number of those on whom status is bestowed' (Marshall, 1950: 18). Social democratic principles of equality through the rights conferred by citizenship at last seemed in the 'golden age' of state welfare to be emerging triumphant over the previously dominant liberal principles of unequal competition between individual agents in the free market.

In its insistence on gradual, peaceful reform, social democracy was credited by Marshall, among others, as creating the welfare state from above as the culminating point of the long march of civilised progress of the British nation by far-sighted individuals committed to high-minded ideals like equality, social justice and national unity. Marshall's form of social democracy told its own story of the triumph of social evolution as represented by the welfare state: 'the modern drive towards social equality is, I believe the latest phase of an evolution of citizenship which has been in continuous progress for some 250 years' (Marshall, 1950: 7). Until then feudal society made any claim to social justice a rather arbitrary affair based on the status enjoyed (or not) by social position rather than citizenship rights in the modern sense. Social relations under feudalism ensured that there was no such thing as separate rights 
available equally to every member of society. It is only fairly recently that any such thing could be conceived and, indeed, for Marshall (1950: X) it was 'only in the present [twentieth] century, in fact I might say only within the last few months' that modern citizenship rights were finally granted. This evolutionary story situates Marshall, like social democracy more generally, in the Whig tradition of historical understanding. Whig history constructs a linear narrative to arrange the past according to the expediency of pressing ideological needs in the present (Butterfield, 1932). ${ }^{2}$

Social democratic Whiggery is forcefully advanced by Marshall as he unfurls a story of the steady progress of equality over the years until he reaches the summit of evolution in the months immediately before he gave his lecture. Class is made by Marshall to conform to an evolutionary ideal where the worst inequalities are erased through the rights and duties of comprehensive citizenship whose entitlements emerge from simply belonging to an increasingly just and orderly national community. This is perhaps understandable from Marshall's Idealist perspective of creating an orderly and more equal society. In 1949 he stood at the opening-up of what many consider the 'golden age' of the welfare state and corporatist state management of the capitalist economy (Harris, 1972). From these heights rational social and political change could seem very much like a top-down affair, something that has an impact on lower classes and other social groups but that they themselves play little part in making.

Famously, full citizenship depended for Marshall on the progressive capture of three kinds of rights: civil rights, political rights and social rights. Each of these elements of citizenship corresponded to certain institutions at definite stages in historical evolution. According to Marshall by the early nineteenth century

\footnotetext{
2 The Whigs were an elite political party between the early eighteenth century and midnineteenth century who defended parliamentary rule against absolutist heredity monarchical rule. A mythical Whig narrative developed around the theme of natural British progress towards liberal democracy against inherited privileges of political power. The origin of the term 'Whig' is somewhat obscure. It seems to derive from the seventeenth century social movement of Scottish radical Presbyterians belonging to 'the Kirk Party' who marched in their thousands with widespread popular support on Edinburgh in 1648 to resist Charles 1. This became known derisively as the 'Whiggamore Raid' after the lowly status of the 'whiggamor' marchers, the Gaelic term for drivers of horse or cattle.
} 
civil rights were established bearing 'in most essentials, the appearance that they have today' (Marshall, 1950:10). Civil rights are those necessary for individual liberty, freedom of speech, the right to justice and, especially important for the emerging society premised on a legally-enforceable exchange between capital and waged labour in 'the right to own property and to conclude valid contracts' (Marshall, 1950: 8). Civil rights were won above all by the courts of justice, whose steady work was only disturbed by popular movements animated by the French revolution: 'This eighteenth-century achievement, interrupted by the French revolution and completed after it, was in large measure the work of the courts, both in their daily practice and also in a series of famous cases in some of which they were fighting against parliament in defence of individual liberty' (Marshall, 1950: 10). Above all, the individual right was won for adult males to freely chose an employer rather than being tied for life as an indentured serf or servile peasant.

Indeed, while Marshall (1950: 11) grants the courts the main role in establishing civil rights he also concedes that the courts were merely ratifying the new reality of free wage labour: 'The Common Law is largely a matter of common sense'. In other words, 'the generally accepted way of life' mentioned by Marshall was already in the throes of change well before the courts and Common Law formalised the new civil right to become free wage labourers. Moreover, by emphasising the role played by law-makers Marshall seriously understates the symbolic use of the language of civil rights in the plebeian culture of 'free-born Englishmen' to legitimately raise a protest against meagre Poor Law administration in times of want and to force concessions from the gentry (see chapter 2). As E.P. Thompson (1991: 74) summarised the reciprocal nature of eighteenth century rights: 'The plebs were aware that a ruling-class that rested its claim to legitimacy upon prescription and law had little authority to over-rule their own customs and rights'.

Political rights took longer to be granted and initially depended on the successful exercise of civil rights to acquire property. Nineteenth century reforms, principally the 1832 Reform Act, extended the franchise to very 
limited sections of society, that of freehold property owners. Not until the 1918 Representation of the People Act was the franchise widened on the democratic basis of equal political rights - albeit limited to 'manhood' suffrage only - rather than on the exclusive basis of property ownership. Nevertheless full political rights even when formally granted, as in the right to vote or stand for election, remained restricted where class prejudice was perpetuated by a deferential attitude among the working class to 'the elites who were born, bred and educated for leadership' (Marshall, 1950: 22). Gradually, in Marshall's narrative, the working class established a political identity independent of elite groups. As they did so, political rights became entwined with the demand for social rights. Universal suffrage was therefore sought by the working class less as an end in itself, as some immanent Idealist unfolding of the democratic principle of equality, than as a means to redress immediate social grievances.

As new civil rights progressed alongside the free market in wage labour a conflict ensued with traditional social rights to protection through local wage regulation and Poor Law support. This reflected the shift from a society arranged by status to one organised by contract. Status conferred by membership of a local community came into conflict with the contract struck between independent individuals in the marketplace. Attempts to regulate the market through the Speenhamland system of a guaranteed wage and family support were doomed to failure under the new spirit of capitalist individualism (Polanyi, 1944). By the time of the 1834 Poor Law Act traditional social rights were forced to retreat more completely under the claims made by free market competition. Forced into the workhouse, and thus into a dependent, nonmarket relationship, the poor and the destitute were denied any scrap of civil or political rights.

By 1950, for Marshall, social rights were enshrined in the equal status afforded by institutions of the welfare state, overturning the domination of life by the laissez-faire contractual bargaining between individuals. 'Social rights in their modern form imply an invasion of contract by status, the subordination of market price to social justice, the replacement of the free bargain by the declaration of rights' (Marshall, 1950: 40). However, Marshall provides little 
sense of the social forces that brought the universal franchise or social rights into existence. He emphasises a clash of incompatible principles rather than a clash of social class interests when he claims that: 'the impact of citizenship on social class takes the form of a conflict between opposing principles' (Marshall, 1950: 18). By focusing on principles and ideals Marshall's Whig history tends to impose an idealist teleology on the history of welfare and downplay material constraints and opportunities. Political reforms therefore appear as the Idealist demi-urge of an evolutionary principle of equality rather than an unceasing, now open/now hidden struggle between antagonistic social groups. Hence, for Marshall the principles of equality embodied in citizenship rights are 'at war' with the principles of inequality embodied in the capitalist class system. Such principles animated the emerging package of social rights - 'from the right to a modicum of economic welfare and security to the right to share to the full in the social heritage and to live the life of a civilised being according to the standards prevailing in the society' (Marshall, 1950: 8). Status therefore depends upon principles while contract depends upon interests. Attempts to establish an 'equality of status' rather than an equalisation of incomes indicates that conflicts over the wage contract are essentially something secondary, as Marshall notes in his discussion of trade unionism.

It is only outside of formal political citizenship that Marshall recognises an alternative source of social power. In the trade unions' creation of a parallel system of 'industrial citizenship' the working class used their combined civil rights as free wage labour to demand social rights. 'These civil rights became, for the workers, an instrument for raising their social and economic status, that is to say, for establishing the claim that they, as citizens, were entitled to certain social rights' (Marshall, 1950: 26). This demand by trade unions for social rights was heard, Marshall notes, during the industrial militancy of the Great Unrest (1910-1914) that swept Britain in the years before the First World War. By 1950 trade unions could defend social rights by working collaboratively within government, whereas 'in the past trade unionism had to assert social rights by attacks delivered from outside the system in which power resided' (Marshall, 1950: 41). For Marshall this means that trade union 
leaders must respect 'the duties of citizenship', above all political stability and social order, and take 'responsibility' for the wider welfare of the national community. Unofficial action by the trade union rank and file represents a repudiation of responsibility, acting in their own narrow self-interest as a throwback to an earlier phase in the evolution of social rights. Since this is one of the few times that Marshall (1950: 41) considers in any detail the role played by subjective agency from below it is worth quoting his thought in full:

Trade union leaders in general accept this [responsibility], but this is not true of all members of the rank and file. The traditions built up at a time when trade unions were fighting for their existence, and when conditions of employment depended wholly on the outcome of unequal bargaining, make its acceptance very difficult. Unofficial strikes have become very frequent, and it is clear that one important element in industrial disputes is discord between trade union leaders and certain sections of trade union members. Now duties can derive either from status or from contract. Leaders of unofficial strikes are liable to reject both. The strikes usually involve breach of contract or the repudiation of agreements. Appeal is made to some allegedly higher principle - in reality, though this may not be expressly asserted, to the status rights of industrial citizenship ... In some recent unofficial strikes an attempt has, I think, been made to claim the rights both of status and of contract while repudiating the duties under both these heads.

Rank and file union members show scant regard for the formal duties of citizenship and insist on the informal democracy of unofficial action in defence of their contractual rights. Such action placed strikes and other forms of what became known as 'extra-parliamentary action' outside the terms of national citizenship. Workers taking industrial action in their own interest were consigned to the status of irrational Others, acting on the fringes of reason and responsibility.

Marshall's formal sociology of citizenship tidies away the haphazardly strewn historical material of class struggle and social movements. Absent is any 
consideration of the role of the urban bourgeoisie in mobilising the apparently natural claim of civil rights in its conflict with the feudal rights of the ancien regime. Neither is there much recognition of the role played in the struggle for political rights by the emergent working class movements like the Chartists (Thompson, 1984). Finally, while there is some mention of trade unionism in the struggle for social rights, the wider context of the labour movement and the proximity of a revolutionary threat, and the dangers of wartime mobilisation in the development of state welfare is overlooked. Outside of antagonistic social interests, Marshall's 'principles' of equality arise deus ex machina from a 'social conscience' that wishes to alleviate the worst aspects of class suffering, 'class-abatement' insofar as it maintains existing class relations. From the Idealist heights of social administration, Marshall naturalises class inequalities by comparing it to environmental 'nuisances' like the acrid smoke belching from factory chimneys: 'And so in time, as the social conscience stirs to life, class-abatement, like smoke-abatement, becomes a desirable aim to be pursued as far as is compatible with the continued efficiency of the social machine' (Marshall, 1950: 20). As Tom Bottomore (1992: 73) summed up the limits to Marshall's teleological history of citizenship rights:

Specific social groups were involved in the struggle to extend or restrict such rights, and in these conflicts social classes have played a major part. Marshall recognised that a measure of conflict existed but he expressed it as a clash between opposing principles rather than between classes, and his discussion of class was primarily concerned, as he said, with the impact of citizenship on social class, not with the ways in which the historical development of classes had itself generated new conceptions of citizenship and movements to expand the rights of citizens.

Marshall was always at pains to champion social justice and equal opportunity within a social democratic framework. Later when a new wave of social movements made themselves felt in the 1960s and 1970s, Marshall (1972) turned his attention to what he called the value-problems of welfare- 
capitalism'. Unless the value demands of the protest movements are accommodated within the social framework of representative government, the mixed economy and the welfare state, Marshall (1972: 32) argued, the alternative would be some variant of totalitarian rule: 'The transformation sought by the more purposeful and less destructive sections of those voicing our present discontents is one of attitudes and values rather than of basic structure, though institutional change changes are sought as a means to this end, as is also the protection of the environment'. Marshall could not foresee at this stage that the alternative was not one between the value-rationality of deepening social democracy or the bureaucratic rationality of Stalinism.

It may be that Marshall was simply proposing an ideal-type evolutionary schema as a heuristic device for understanding his trinity of rights. While his essay depends on this kind of purchase from Idealist reductionism, he is also concerned throughout to appeal to the empirical basis for the emergence of social rights. His essay can be seen as both a guide to thinking about rights and an historical interpretation of the specific case of England (rather than Britain). Be that as it may, an Idealist commitment to evolutionary Whiggery prevented Marshall from registering that the onset of crisis and the emerging ideology of the New Right would herald a neoliberal attack on the values of welfare capitalism for an entire generation. It is the concern of the rest of this chapter to outline the contested, non-teleological development of welfare rights, understood not merely as the clash of competing principles but also as the clash of antagonistic social forces. This will, arguably, demarcate the ground upon which both the rise of new social movements and the neoliberal counter-assault were prepared.

\section{The New Left, reform and protest}

An alternative socio-historical framework for understanding the rise of state welfare emerged within ten years of Marshall's account. In the second half of the 1950s a generation of politically engaged historians and intellectuals of the British New Left challenged some of the political assumptions of the times (Chun, 1995; Kenny, 1995). Disillusioned with Stalinist dogma and the orthodoxy of the Communist Party of Great Britain, and revolted by its 
uncritical support for the Soviet repression of the Hungarian Uprising in 1956, a number of talented socialist intellectuals attempted to create a new, independent social and political movement through the critical rejuvenation of Marxist ideas. Out of this milieu, a socio-historical approach to the welfare state was given a particularly sharp expression by the Marxist historian John Saville (1957-8). Almost as a detailed rejoinder to Marshall, in his 1957 essay for the New Left journal New Reasoner, Saville challenges the idea that the welfare state represents a staging post in the inevitable path to socialism and equality. Instead, Saville (1957-8: 5-6) argues, the welfare state emerged thanks to the interaction of three underlying dimensions:

(1) the struggle of the working class against their exploitation; (2) the requirements of industrial capitalism (a convenient abstraction) for a more efficient environment in which to operate and in particular the need for highly productive labour force; (3) recognition by the property owners of the price that has to be paid for political security.

It is not only class struggle that determined the shape of state welfare. Social policy also became a functional precondition for the further accumulation of capital and the political concessions granted under the framework of liberaldemocratic institutions provided the best shell for channeling social antagonism away from more incendiary forms of protest and struggle.

In his claim that 'it is not the middle class or any group of property owners who have been the prime mover in social change', Saville (1957-8: 9) does not attempt to minimise the role played by the challenge from below of the labour movement. His point is that the more thoughtful and enlightened sections of the ruling class began to converge with the demands of working class socialism for the need for a more thorough programme of radical reform. In this way fundamental disputes between the classes about property rights might be avoided or mitigated in the interests of economic efficiency and political stability. This has some echoes with Marshall's claims about classabatement and abatement of conflict, as well as a longer tradition of radical New Liberal thought and middle class reformism like the Fabianism of the 
Webbs. However, Saville (1957-8: 9) departs radically from Marshall's claim that 'social conscience' animated by higher values and collective principles of citizenship was the bedrock cause of social reform: 'Social conscience, except in the hearts and minds of a small minority among the middle class is a frail instrument of social policy, and conscience normally requires the support of some powerful "interest" before it is translated into practice'. As a Marxist, Saville (1957-8: 10) instead holds that social reform is the product of class struggle, where the shape, organisation and determination of working class pressure from below determines the evolution of state welfare, and that the ruling class only concedes reforms reluctantly and grudgingly: 'Only the massive development of the working class movement and the recourse to methods of direct action have been able to shift the mountains of unreason that have built themselves upon the foundations of private property'.

After the shock to bourgeois values represented by Chartism and the state repression that followed the 1848 mass mobilisation the working class became ever more firmly locked outside the formal politics of parliamentary democracy (Saville, 1990). In this void workers developed their own defensive organisations in the form of trade unions created by and for skilled craftsman. At the height of its mobilisations in 1839, 1842 and 1848 Chartism threatened to overturn existing property relations so dangerous was the demand for basic democratic rights in those years (Charlton, 1997). The 'six points' of the Charter - universal suffrage, equal representation, removal of property qualifications, annual parliaments, payment for MPs, and use of the ballot provided a focus for the formation of a truly national working class movement across the length and breadth of Britain (Thompson, 1984). This was far from the evolutionary course of events plotted by British Whig History where reason would sooner or (more usually) later prevail over the militant hotheads making utopian demands for democracy and social justice in the here and now. Both the 1832 Reform Act and the 1834 Poor Law Amendment Act decisively excluded the working class from participation in the official political of British democracy, setting the context for the mass movement that grew up in support of the Charter mobilisations in the late 1830s and 1840s. As Charlton (1997: 84) puts it, 'If there was any hint that the Charter might have 
been a means for the middle class to siphon off working class fury over the New Poor Law it was blown apart by the belligerent mass meetings in the North in 1839, the South Wales Rising and the partial uncovering of insurrectionary plotting in several parts of the country'.

The franchise was only gradually extended to the working class in the period from 1867 until 1918, and 1927 for working class women. But where Marshall might see this as part of the natural evolutionary course in the typically British tradition of slow but sure political reform, Saville views it as a stalling game by the ruling class to deflect the potential political power represented by the numerical superiority of proletarian voters. Delay in the introduction of basic political rights for the working class by a few decades allowed the Tories and the Liberals to occupy more favourable ground than their previous defence of an exclusive right to property might suggest. Saville (in 1957-8: 14) quotes the Radical Liberal Joseph Chamberlain from an 1885 speech advocating an early blue-print of the welfare state: 'what ransom will property pay for the security which it enjoys?' In the conflict between the civil rights of contract and the social rights of status far-sighted Liberals made judgements about how to cope with the democratic 'ransom' that the working class would inevitably demand. Which outcome overall would best maintain political stability and existing property relations became a pressing matter of elite reflection. A judicious approach to reform from above represents the obverse side of elite fears of radical working class mobilisation from below. Saville notes that this tactic also had the effect of delaying the emergence of a mass-membership socialist party in Britain and, it might be added, clouded the reception of Marxism within the British labour movement (Hobsbawm, 2007).

When the Labour Party finally emerged it immediately came under the influence of liberal reformism, 'Lib-Labism', and initially refused to let itself be known as a 'socialist party' (Miliband, 1972). Here the influence of the Fabian Society proved decisive in defining the ideological terrain of state welfare, building on the ideals represented by the New Liberalism. Fabianism stressed the practical and pragmatic nature of reform where the nineteenth century state was already compelled by efficiency claims, as much as by the claims of 
social justice, to intervene in market relations to alleviate widespread hardship. For leading Fabians like Sidney and Beatrice Webb 'practical men' oblivious of or hostile to any collectivist ideology had by the turn of the twentieth century already come to depend on the 'unconscious socialism' of municipal planning and Public Health legislation (Briggs, 1962). Crucial here was the idea that once 'the facts' of social degradation were exposed before a well-meaning middle class public their social conscience would be stirred into action and such rational minds would be compelled to accept the tide of collective provision rather than fight against it. More radical working class demands for the full franchise and a more comprehensive transformation of the social structure could thereby be stilled by judicious elite action. As Sidney Webb complained in 1896, 'The difficulty in England is not to secure more political power for the people, but to persuade them to make any sensible use of the power they already have' (in Bruce, 1968: 161).

Having established the constellation of conditions - class struggle, economic efficiency and political stability - that precipitated greater state intervention for the collective provision of welfare, Saville (1957-8: 16-17) identifies the three phases of reform in the first half of the twentieth century. First, the wave of Liberal reforms of 1906 to 1914 included:

1906 meals for deprived school children 1907 medial inspection for school children 1908 first old age pensions 1909 introduction of minimum wage for selected industries 1911 beginning of national health and unemployment insurance

Second, Saville gives the example of how the ruling class rode out the high point of working class militancy in 1919 through delay, evasion, and concession, while Lloyd George cleverly outflanked the tamely inept leadership of the Labour Party and the trade unions. Hence the reforms of the interwar Conservative and Labour Governments were piecemeal reflections of an emerging 'middle way': 
1918 Maternity and Child Welfare Act

1919 Housing and Town Planning Act

1920 Unemployment Insurance Act

1926 Haddow Report on education

1927 Widows, Orphans and Old Age Contributory Pensions Act

1934 Unemployment Act

Finally, the 1945-1950 Labour Government introduced what became the modern welfare state. Standing so close in time to Labour's welfare reforms Saville (1957-8: 17) is careful to indicate that the welfare state was not as radical as has since been portrayed in many 'golden age' accounts but represented a minimum programme of reform acceptable to the Conservative opposition: 'It was a modest programme, and a couple of decades overdue by the standards of the previous half century and its achievement was followed by a partial retreat in 1950 with the imposition of charges for certain health services'. In some respects the welfare state must be considered a success for those that opposed any 'socialist measures' that threatened to interfere with the workings of the free market, including the market in wage labour. 'Since the welfare state in Britain developed within a mature capitalist society, with a ruling class long experienced and much skilled in the handling of public affairs, its growth and development has been slow and controlled; and the central interests of property have never seriously been challenged' (Saville, 1957-8: 24).

The radicalisation of British society provoked by wartime measures led to a mainstream consensus across the Labour and Conservative parties that managed reform was preferable to unchecked grievances from below (Calder, 1969). As the Conservative Quentin Hogg (later Lord Hailsham) put it in a debate in the House of Commons in 1943: 'If you do not give the people social reforms they are going to give you social revolution' (Hansard, 17 February 1943). After decades of winning at best piecemeal reforms the labour movement came to regard the welfare state as its lasting achievement, a valedictory lesson for the futility of more radical protest movements led by the Communist Party and the Independent Labour Party which in the past had 
made unrealistic demands for the socialist transformation of society. 'The struggle for any particular reform has always in this country aroused so much opposition that when it is achieved it is at least understandable that those who have spent half a lifetime on its behalf too easily believe that with its enactment a new period of social history is beginning' (Saville, 1957-8: 17).

This was true for at least the more reformist sections of the New Left who argued that state welfare combined with the Labour government's programme of nationalisation represented a 'transition to socialism'. In the debate in the pages of The New Reasoner that followed Saville's essay, Dorothy Thompson (1958) contended that the British welfare state was 'profoundly anti-capitalist' because services are provided on the basis of need rather than ability to pay. By reducing social reforms as mere 'palliatives' that the ruling class were prepared to concede anyway, Saville had minimised the role played by the 'mass pressure' of the working class:

It had to be fought for at every stage, and although the leaders of individual campaigns - such as those for family allowances or free school meals, may have appeared to be isolated humanitarians, their support has always come from the organised labour movement - as well, of course, as from humanitarians in all parts of society. What is more, the opposition has always come from the spokesmen of property, and it significant that the first move made by Conservative chancellors when a reduction in government expenditure is called for has been towards these same services. This is not only because the government itself hates them, but because the whole political philosophy of those who support such governments is against the conception of need as a criterion of service. (Thompson, 1958: 127-8).

For Thompson, working class organisation and values, the objective function of public sector welfare workers, the growing scale of the capitalist enterprise, and the internal divisions of the ruling class all indicate that capitalism is incubating the future socialist society in the womb of the existing society. State welfare represented a material victory for working class movements and 
values, what Marx called 'the political economy of the working class', of 'social responsibility and human dignity' prevailing over exchange and profit. In their commitment to public service rather than private profit teachers, doctors, and health workers constitute 'an objectively anti-capitalist force in society' (Thompson, 1958: 129). Social reform is less a demonstration of the impregnable unity of the ruling class in their ability to delay, fudge and deflect state welfare, so emphasised by Saville, than an indication of the deep divisions within their ranks, which, in their mutual antipathy and competition with each other, sometimes breaks out into open civil war. State welfare is only possible where an ideological or political crisis exposes such divisions as they emerge from the internal competition among capitalists, with the larger, more efficient producer consuming the weaker, less efficient one, ultimately precipitating a crisis of the entire system of private property. 'The combined demands for social services and higher wages put forward by the working class will continue to drive out the less efficient capitalist, and to tax the national productive capacity, perhaps to breaking point' (Thompson, 1958: 129). Attempts would indeed be made to resolve imbalances between tax revenues and social welfare benefits but in ways that would reverse any supposed line of evolution towards socialism.

This optimistic, evolutionary prognosis was widely-held by the labour movement and social democratic intellectuals at the time. It was also widely felt that there would be continuous forward movement towards equality, something that was rudely discounted by Saville's prescient internationalist insight that the decline of British imperialism would place added strains on the British economy to continue to deliver welfare improvements: 'When therefore we accept, and rightly, the achievement of the Welfare state as the product of working class agitation and struggle, we should also be clear that a part, at least, of the flexibility and maneuverability of the ruling class has been derived from the possession of the world's largest Empire' (1957-8: 24). Only later would it become clear that this view of state welfare as a supposedly privileged site for the 'organic national unity' of white male Britons was also rapidly becoming untenable with immigration from Asia and the West Indies, not least to occupy the lowest rungs of the welfare state hierarchy (Williams, 
1989). Saville is also concerned that the very success represented by the welfare state and large-scale political trade union organisation had become 'social and political shock absorbers', demobilising struggles from below by confusing a more comprehensive socialist programme with improved living standards and levels of security that were contingent on the post-war economic boom. In such ways the labour movement became tied up in ideological knots: 'on the one hand since they are the result of struggle, the labour movement has grown stronger with success; on the other, since so far social and economic reforms have easily been absorbed into the economic system, there is an immense confusion of ideas as to what exactly has been achieved' (Saville, 1957-8: 24).

As the mythical national consensus around 'fair shares for all' and British 'fair play' began to breakdown in the 1960s the kind of critique raised by Saville against Marshallian approaches to British citizenship became more widely shared by an emerging generation of activists and intellectuals. Hence, by the mid-1960s Dorothy Wedderburn (1965: 143) could echo Saville's emphasis on the need 'to focus attention on the demands of the working class for social justice and upon an analysis of the political strength of the working class; and its success in winning allies from particular pressure and interest groups'. By then new social movements, student radicalism, anti-racist struggles, secondwave feminism and working class struggles were beginning to emerge to redefine the terrain upon which state welfare would be contested over the next decade and beyond. And, waiting in the wings, a counter-assault would emerge to selectively assimilate previously marginal agendas of the new social movements while attempting to roll back the seemingly unassailable gains of state welfare and the forces that made them.

\section{Conclusion}

People do not make history in conditions that they themselves have freely chosen. This sociological axiom illuminates our understanding of the formation, development and reproduction of the institutions of the welfare state. According to this axiom a number of inter-related elements have been forefronted in this chapter that are often neglected or downplayed in the study 
of social policy. Conflicting understandings of the historical making of the welfare state emerged from the post-war debate represented by Marshall and Saville. It is clear that the relationship between social movements and social policy is always a multi-faceted one. We want to highlight five core elements from this chapter:

1. the subjective role of collective agency;

2. the limits and possibilities of objective institutional structures;

3. historical continuities and discontinuities;

4. the role played by values, ideas and principles; and

5. popular mobilisation from below.

First of all, the Marshall-Saville debate in this chapter helped re-establish the importance of subjective agency in historically shaping the contours of state welfare. For Marshall agency is bound up with those elite institutions that support civil, political and social rights; for Saville agency concerns the contending sides in the struggle between the classes.

Second, the historical preconditions are both constraining - people encounter objectively-given conditions that places limits on what they can realistically do - and permissible - these conditions permit and support, as well as prohibit social actions of various kinds. Through the collective agency of social movements objectively-given conditions are themselves altered in the process. A centrally important discovery of the chapter is that institutional structures not only inhibit social action they also make social action possible in the first place. While Saville is alive to the power of ruling groups to frustrate, reduce and delay reform as an objective constraint on working class demands, Marshall presents us with a vision of British historical evolution as an expression of the civilized values that unifies the national community. The result is an abstract form of agency without a subject.

Third, history is punctuated by discontinuous moments of change. The history of the welfare state is not simply an evolutionary, 'upwards and onwards' steady march of progress as Marshall would have it. State welfare has equally 
been shaped by dramatic moments of conflict and contention, as well as more mundane forms of resistance and passive acquiescence. As Saville explained, the history of social policy has therefore been marked by sharp discontinuities in the ideological legitimation and institutional politics of welfare. On the other hand, systemic continuities are represented by the survival of private property, although this can sometimes be muffled by the ideological contention over the meaning and significance of state reforms and public provision.

Fourth, agency is not an exclusively top-down prerogative. In many influential accounts state welfare appears as if it was the creation of far-sighted and benevolent elite institutions and individuals sharing in a national value consensus. As we have seen, for Marshall and Fabian reformism a social conscience is stimulated by rational arguments conducted at the apex of representative interest groups and qualified experts. Persuasive appeals are made to ethical values, the empirical evidence and a pragmatic approach to social reform. Both Marshall and Saville share a concern to establish the important role played by far-sighted elite groups introducing reform from above, managing and controlling its extent and nature. On the other hand, Saville's historical materialism registers the different facets of welfare reform in the structures of divergent class interests within capitalism, whereas Marshall invokes the growing convergence of principles in a value consensus spread across class society.

Finally, as Saville demonstrates, the structure of society at any point in time sets definite limits and constraints on the kind of social action that is possible. But, conversely, social action through popular mobilisation has an effect, directly or indirectly, on the very nature of the social structure. In other words, agency from below cannot be consigned to a political or social vacuum by the wiliness of ruling class stratagems. The following chapter selectively examines concrete historical examples of protest and principle in the making and deflection of social reform. It also centrally explores the contribution that social movements make to our understanding of state welfare. 